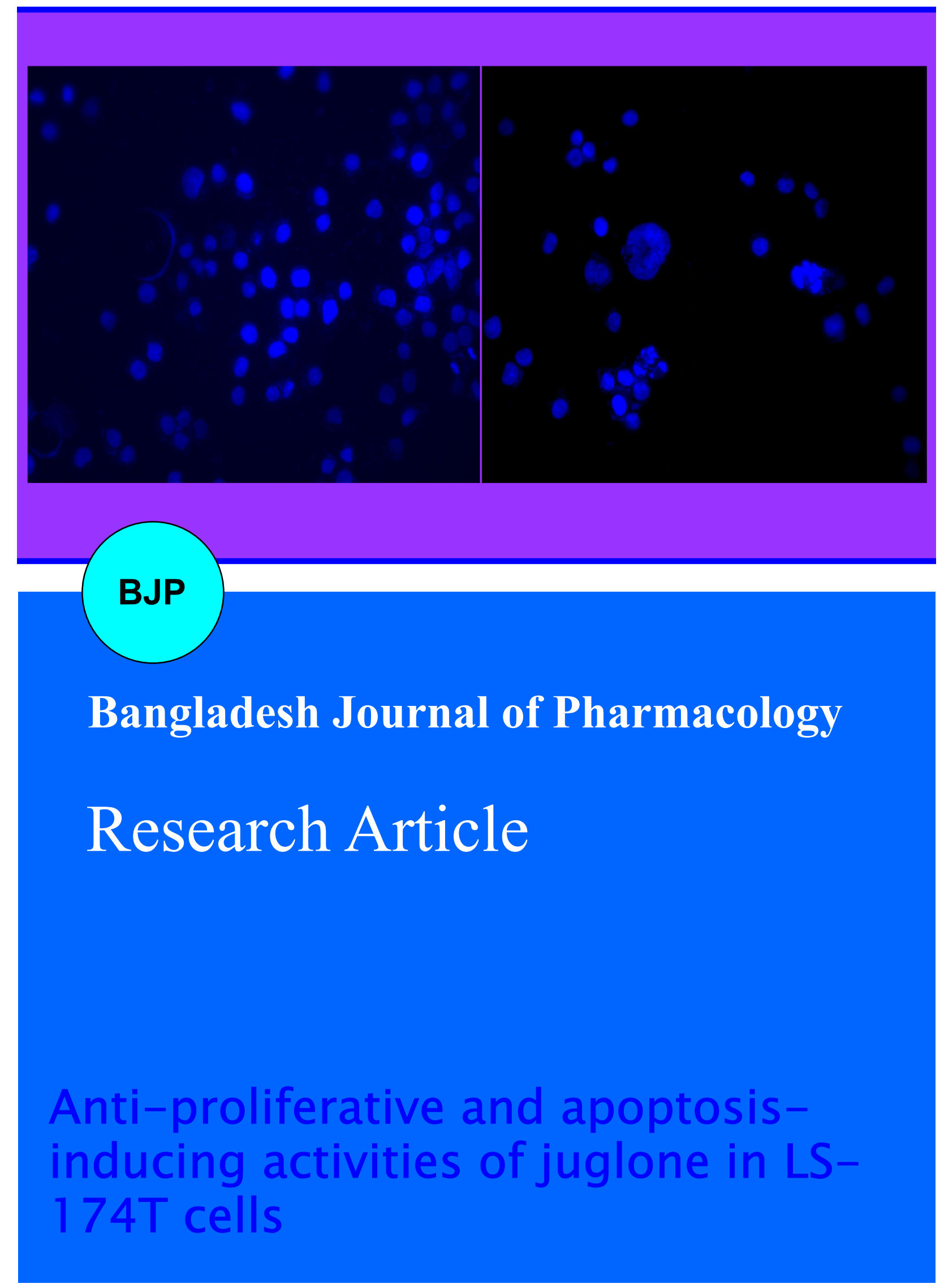




\title{
Anti-proliferative and apoptosis-inducing activities of juglone in LS-174T cells
}

\author{
Qiang Li', Xue Ling Zhao', Juan Sun', Shou Gang Jiang' and Xian Feng Gong1 \\ ${ }^{1}$ School of Chemistry and Materials Science, Heilongjiang University, Harbin 150080, PR China; ${ }^{2}$ Key Laboratory of \\ Forest Plant Ecology, Ministry of Education, Northeast Forestry University, Harbin 150040, PR China.
}

\begin{tabular}{l} 
Article Info \\
\hline Received: $\quad$ 2 January 2013 \\
Accepted: $\quad$ 14 January 2013 \\
Available Online: $\quad$ 27 January 2013 \\
DOI: $10.3329 /$ bjp.v8i1.13174 \\
\\
Cite this article: \\
Li Q, Zhao XL, Sun J, Jiang SG, Gong \\
XF. Anti-proliferative and apoptosis- \\
inducing activities of juglone in LS- \\
174T cells. Bangladesh J Pharmacol. \\
2013; 8: 65-72.
\end{tabular}

\begin{abstract}
Anti-proliferative and apoptosis-inducing effects of juglone in LS-174T cells were investigated. In this study, we showed that juglone inhibited the proliferation of LS-174T cells in a time and dose-dependent manner, treatment of juglone resulted in the activation of caspase-9 and 3, decrease of Bcl-2. Nacetylcysteine significantly attenuate LS-174T cell death induced by juglone $(p<0.001)$. In addition, NAC could reverse caspase- 3 and 9 activation, increase expression of $\mathrm{Bcl}-2$ protein. Taken together, these findings indicated that juglone-mediated oxidative injury may act as upstream change, trigger ROS release, Bcl-2 modulation, caspase activation, and consequently leading cell apoptosis in LS-174T cells. In conclusion, these findings suggest that juglone may be an effective way for treating human cancers.
\end{abstract}

\section{Introduction}

Quinones represent a broad category of widely distributed quinoid compounds in nature. Many quinones have been associated with a range of biological activities, including anti-cancer activity (Babula et al., 2007). Juglone (5-hydroxy-1,4-naphtha-quinone) (Figure 1) is a quinone found in the roots, leaves and bark of walnut trees (Inbaraj et al., 2004; Varga et al., 1996).

The bark, branches and exocarp of the immature green fruit of walnut trees have been used to treat gastric cancer, liver cancer, lung cancer and other types of cancer for a long time in China (Liu et al., 2004). Juglone has cytotoxic properties when administered to cell cultures (Inbaraj et al., 2004; Kamei et al., 1998; Rippmann et al., 2000; Kiran et al., 2009; Ji et al., 2009.) and it possesses antiviral, antibacterial and antifungal properties (Clark et al., 2006; Inbaraj et al., 2004). In addition, juglone promotes generation of hydrogen peroxide (Inbaraj et al., 2004), block of $\mathrm{K}^{+}$channel (Varga et al., 1996) and inhibition of transcription (Chao et al., 2001). Furthermore, benzobijuglone, a novel cytotoxic compound from Juglans mandshurica, could induce apoptosis in HeLa cells (Li et al., 2007).

In this paper, we investigated the anti-proliferative and apoptosis-inducing effects of juglone in LS-174T cells. The work reported here is focused on which components of apoptosis pathway were involved in cell death, and whether reactive oxygen species (ROS) have a role in LS-174T cells death induced by juglone. Although some groups have studied the in vitro cytotoxic activity of juglone against cancer cell lines (Kamei et al., 1998; Segura-Aguilar et al., 1992), the exact mechanism remains doubtful. Therefore, we investigated the cytotoxic potential of juglone and its underlying mechanisms.

\section{Materials and methods}

\section{Materials}

Juglone was kindly gifted by Dr. Ma Zhiqiang. The purity of jugone was measured by HPLC and determined to be $97 \%$. Juglone was dissolved in dimethyl sulfoxide (DMSO) to make a stock solution. The concentration of DMSO was kept below $0.3 \%$ in all the cell 
cultures and did not exert any detectable effect on cell growth. 3-(4,5-dimethylthiazol-2-yl)-2,5-diphenyltetrazolium bromide (MTT), Hoechst 33258, RNase A, Proteinase K and N-acetyl-L-cysteine (NAC) were purchased from Sigma Chemical (USA). Cell Death Detection ELISAPLUS was purchased from Roche (Roche Molecular Biochemicals, Germany). Western blotting antibodies against caspase-3, 9 and alkaline phosphatase conjugated secondary antibodies were purchased from Santa Cruz Biotechnology (USA). Antibody against Bcl-2 was purchased from Abacam (Cambridge, MA). Antibodys against PARP and caspase-3 colorimetric activity assay kit were purchased from Beyotime Institute of Biotechnology (Haimen, Jiangsu).

\section{Cell culture}

LS-174T, human colon adenocarcinoma cell line (ATCC CL-188), were cultured in RPMI-1640 medium (Hyclone, Logan, UT) supplemented with 10\% heat inactivated $\left(56^{\circ} \mathrm{C}, 30 \mathrm{~min}\right.$ ) fetal calf serum (Hangzhou Sijiqing Biological Engineering Materials Co., Ltd., Zhejiang), $2 \mathrm{mM}$ glutamine (Gibco, Grand Island, NY), and maintained at $37^{\circ} \mathrm{C}$ with $5 \% \mathrm{CO}_{2}$ in a humidified atmosphere.

\section{Cell growth inhibition test}

The inhibition of cultured cells was determined by MTT test (Rasu Azhar et al., 2012). In brief, after incubation with juglone $(0-200 \mu \mathrm{M})$ for indicated time period, LS$174 \mathrm{~T}$ cells $\left(5 \times 10^{4} /\right.$ well $)$ in 96-well plate were washed once with PBS and MTT ( $20 \mu \mathrm{L}$ of $5 \mathrm{mg} / \mathrm{mL}$ in PBS) was added to each well. The cells were further incubated at $37^{\circ} \mathrm{C}$ for 4 hours, and DMSO $(150 \mu \mathrm{L})$ was added to dissolve the formazan crystals. Absorbance was measured at $490 \mathrm{~nm}$ with micoplate reader (BioRad 680, Hercules, CA).

\section{Nuclear damage observed by Hoechst 33258 staining}

After treated by $50 \mu \mathrm{M}$ juglone for 36 hours, LS-174T cells were harvested by centrifugation at 1,000 $\times g$ for 5 min, washed two times with PBS and fixed with 3.7\% paraformaldelyde at room temperature for 2 hours. The fixed cells were washed with PBS and stained with Hoechst 33258 solution for $10 \mathrm{~min}$ at room temperature, then observed with fluorescence microscopy.

\section{Determination of DNA fragmentation by agarose gel electrophoresis}

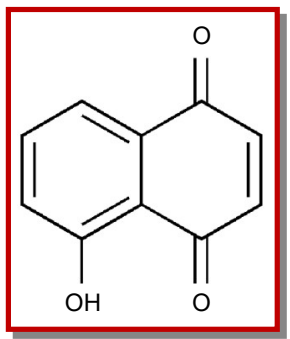

Figure 1: The chemical structure of juglone
LS-174T cells, both adherent and floating, were collected by centrifugation at $1,000 \times g$ for $5 \mathrm{~min}$. The cell pellets were suspended in cell lysis buffer (Tris- $\mathrm{HCl}$ $10 \mathrm{mMpH}$ 7.4, edetic acid $10 \mathrm{mM}$ pH 8.0, Triton-100 $0.5 \%$ ) and kept at $4^{\circ} \mathrm{C}$ for $30 \mathrm{~min}$. The lysate was centrifuged at $25,000 \times g$ for $20 \mathrm{~min}$. The supernatant was incubated with $20 \mathrm{mg} / \mathrm{mLRNase} \mathrm{A}(2 \mu \mathrm{L})$ at $37^{\circ} \mathrm{C}$ for 1 hours, then incubated with $20 \mathrm{mg} / \mathrm{mL}$ proteinase $\mathrm{K}(2 \mu \mathrm{L})$ at $37^{\circ} \mathrm{C}$ for 1 hours. The supernatant was mixed with $5 \mathrm{M} \mathrm{NaCl}(20 \mu \mathrm{L})$ and isopropanol $(120 \mu \mathrm{L})$ at $-20^{\circ}$ $\mathrm{C}$ overnight, then centrifuged at $25,000 \times g$ for $15 \mathrm{~min}$. After drying, DNA was dissolved in TE buffer (Tris$\mathrm{HCl} 10 \mathrm{mMpH}$ 7.4, edetic acid $1 \mathrm{mM} \mathrm{pH} \mathrm{8.0)} \mathrm{and}$ separated by $2 \%$ agarose gel electrophoresis at $100 \mathrm{~V}$ for $50 \mathrm{~min}$.

\section{Enzyme-linked immunosorbent assay for apoptosis}

The Cell Death Detection ELISA kit (Roche Molecular Biochemicals) was employed to quantify DNA fragmentation on the basis of antibody detection of free histone according to the protocol of manufactrure.

\section{Western blot analysis of protein expression}

Western blot analysis was performed as follows. Briefly, LS-174T cells treated with different concentrations of juglone for 36 hours were harvested, rinsed twice with cold PBS, and resuspended in lysis buffer, including Hepes 50 mM pH 7.4, 1\% Triton-X 100, sodium orthovanada $2 \mathrm{mM}$, sodium fluoride $100 \mathrm{mM}$, edetic acid $1 \mathrm{mM}$, egtazic acid $1 \mathrm{mM}$, PMSF $1 \mathrm{mM}$, aprotinin $0.1 \mathrm{~g} / \mathrm{L}$, leupeptin $0.01 \mathrm{~g} / \mathrm{L}$, then lysed in $4^{\circ} \mathrm{C}$ for 1 hours. After 13,000 $\times g$ centrifugation for $10 \mathrm{~min}$, the protein content of supernatant was determined using Bio-Rad protein assay reagent (Bio-Rad, Hercules, CA). Equal amounts of protein $(30-40 \mu \mathrm{g})$ was subjected to $12 \%$ SDS polyacrylamide gels and transferred to nitrocellulose membranes. Membranes were blocked with 5\% defatted milk, and then incubated overnight with the appropriate primary antibody at dilutions specified by the manufacturer, followed by incubation at room temperature for 1 hour with the corresponding alkaline phosphatase conjugated secondary antibody at 1:500-1000 dilution in TBST. Bound secondary antibody was detected using an BCIP/NBT Alkaline Phosphatase Color Development Kit (Beyotime Institute of Biotechnology, Haimen, Jiangsu, China)

\section{Determination of caspase-3 activity}

The activity of caspase- 3 was determined using the caspase-3 activity kit. Briefly, LS-174T cells were seeded in culture flasks $\left(1 \times 10^{6}\right.$ cells/flask $)$ and allowed to attach overnight. After treating the cells with juglone $(12,25,50$ and $100 \mu \mathrm{mol} / \mathrm{L})$ or medium for 36 hours, cell lysates were prepared by incubating $2 \times 10^{6}$ cells in $100 \mathrm{~mL}$ lysis buffer for $15 \mathrm{~min}$ on ice. Cell lysates were centrifuged at $20,000 \times \mathrm{g}$ for $15 \mathrm{~min}$ at $4^{\circ} \mathrm{C}$. Supernatants were collected and added to an ice-cold 


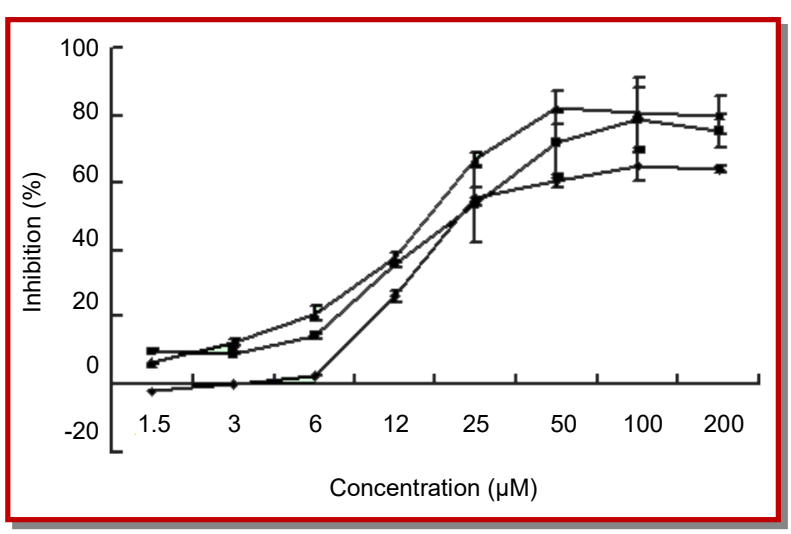

Figure 2: Juglone induces growth inhibition

The cells were exposed to juglone at concentrations ranging from 0-200 $\mu \mathrm{M}$ and incubated for 24 hours ( ), 36 hours ( $)$ and 48 hours ( $(\mathbf{)})$. The inhibitory ratio was measured by MTT assay. Data represent the mean \pm $\mathrm{SD}$ of three independent experiments

centrifuge tube. A blank solution containing $90 \mathrm{~mL}$ reaction buffer and $10 \mathrm{~mL}$ Ac-DEVD-pNA and the sample solution for each group including $80 \mathrm{~mL}$ reaction buffer, $10 \mathrm{~mL}$ sample and $10 \mathrm{~mL}$ Ac-DEVDpNA were incubated in a 96-well microplate for 2 hours at $37^{\circ} \mathrm{C}$. Caspase- 3 activity was measured at $405 \mathrm{~nm}$ using a microplate reader (Bio-Rad 680, Hercules, CA). The active unit of caspase- 3 was calculated. One unit is the amount of enzyme that will cleave $1.0 \mathrm{nmol} / \mathrm{L}$ of the colorimetric substrate Ac-DEVD-pNA per hour at $37^{\circ} \mathrm{C}$ under saturated substrate concentrations.

\section{Statistical analysis}

All experiments were repeated at least three times. The results from treated and untreated control cells were compared using the Student's t-test to assess statistical significance.

\section{Results}

To determine the inhibition of LS-174T cells exposed to juglone, cells were treated with juglone of different concentrations, ranging from 0 to $200 \mu \mathrm{M}$ for 24,36 and 48 hours. Inhibition of LS-174T cell proliferation was in a time- and dose-dependent manner (Figure 2). The $\mathrm{IC}_{50}$ dose of juglone for 24, 36 and 48 hours was approximately 56, 30 and $22 \mu \mathrm{M}$, respectively.

Morphological changes were observed by fluorescence microscopy. Nuclear morphological changes were observed by Hoechst 33258 staining. In control group, cells were round in shape and stained homogeneously. After 24 hours treatment with $50 \mu \mathrm{M}$ juglone, blebbing nuclei and granular apoptotic bodies appeared (Figure 3A).

To further verify apoptosis induced by juglone, the Cell Death Detection ELISA kit was employed to quantify cytoplasmic histone-associated-DNA-fragments (by measuring optical density). The results showed that juglone induced significant apoptotic cell death at 25 and $50 \mu \mathrm{M}$ (Figure 3B). In addition, DNA fragmentation became obvious after 25, 50 and $100 \mu \mathrm{M}$ juglone treatment for 36 hours on agarose gel electrophoresis (Figure 3C), which further confirmed juglone induced cell apoptosis.

To investigate whether caspase- 3 and 9 participated in juglone-induced cell apoptosis, expressions of procaspse- 3 and -9 by western blot analysis were
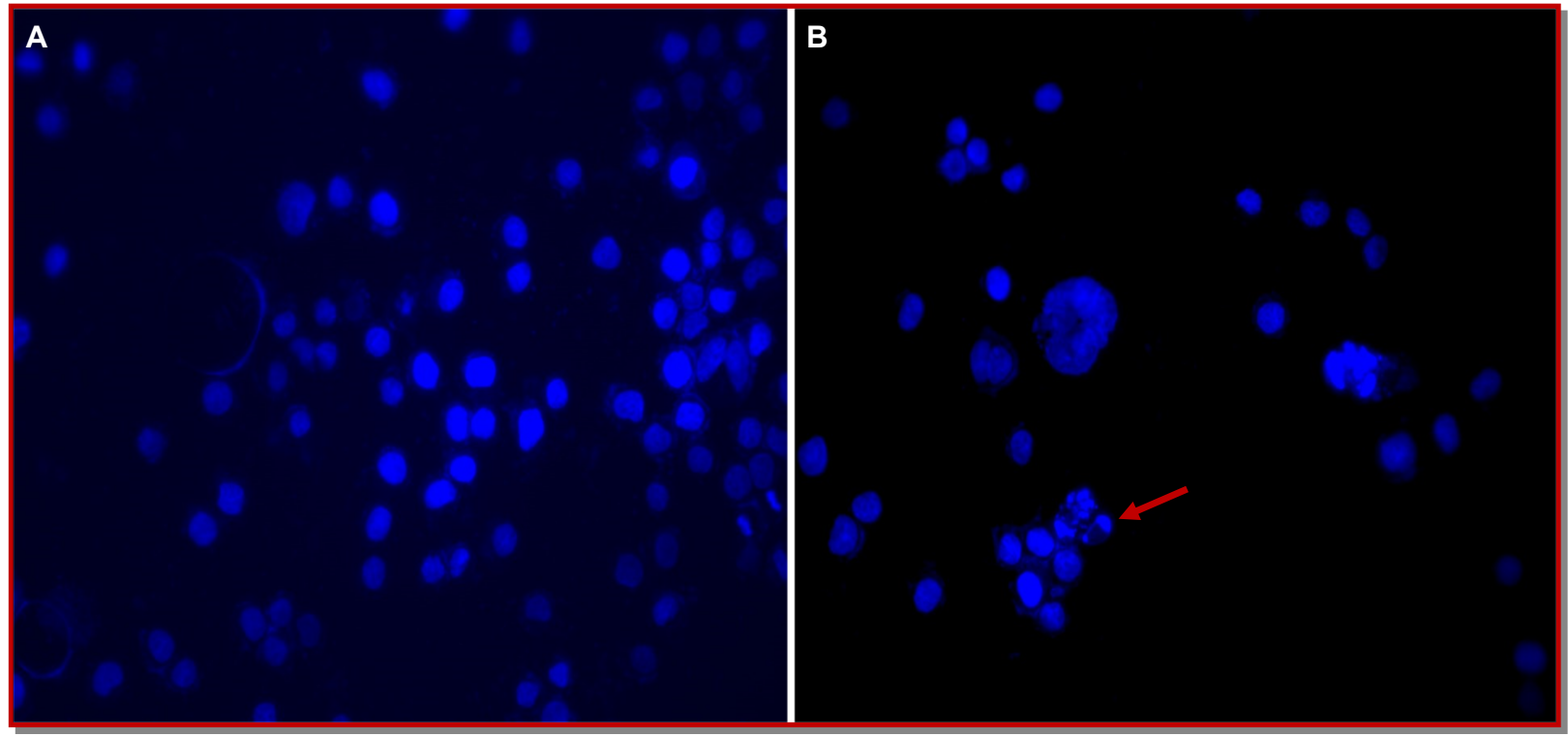

Figure 3A: Juglone-induced apoptotic morphological changes

LS-174T were incubated in the medium alone for 36 hours (A) or in the medium containing $50 \mu \mathrm{M}$ juglone for 36 hours (B). Arrows indicates fragmented nuclei 


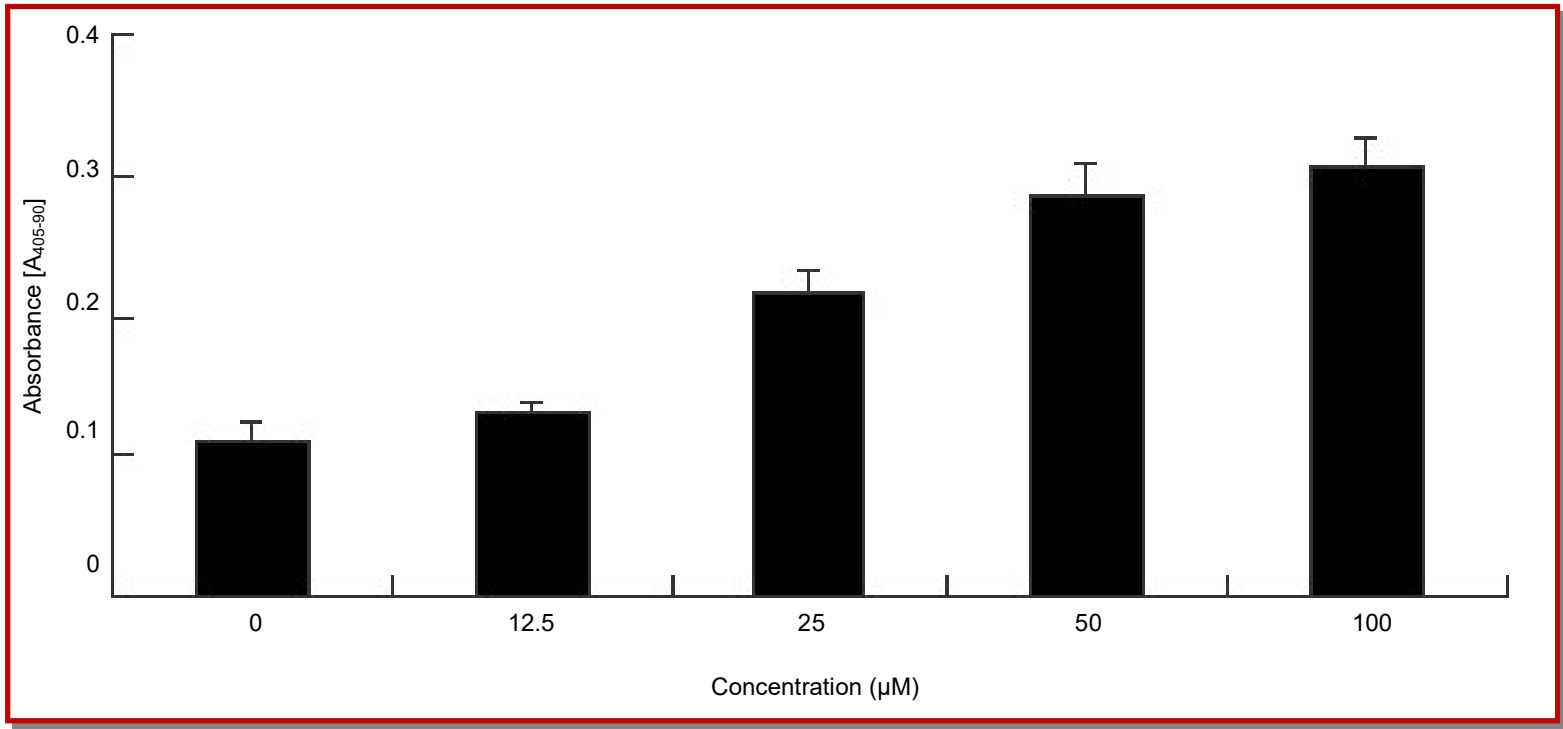

Figure 3B: Pro-apoptotic effect of juglone determined by ELISA quantification of DNA fragmentation expressed as optical density (OD) values

LS-174T cells were incubated in the medium alone or in the medium containing 12.5,25,50 and $100 \mu \mathrm{M}$ juglone for 36 hours (** and

*** stands for $\mathrm{p}<0.01$ and $\mathrm{p}<0.001$ compared with $0 \mu \mathrm{M}$, respectively)

performed. After incubation with juglone of indicated concentrations, expression of procaspse- 3 and -9 protein was decreased, indicating caspase- 3 and -9 activation (Figure 4A).

To further determine whether caspase 3 participated juglone induced apoptosis in LS-174T cells, Western blot analysis was performed to examine the expressions of caspase 3 substrate, PARP, and caspase- 3 activity

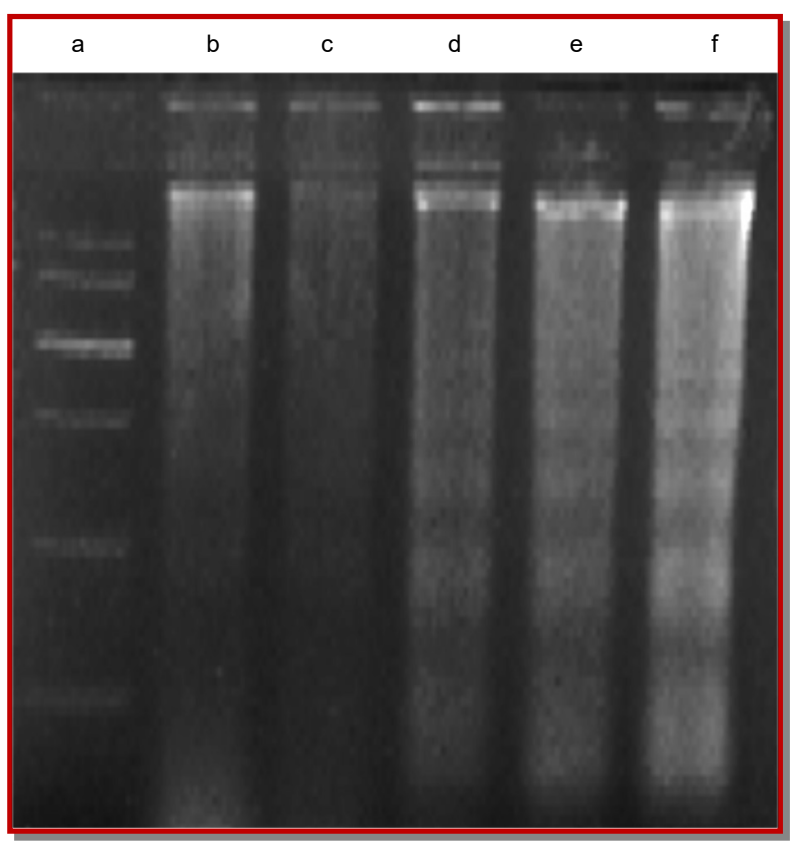

Figure 3C: DNA fragmentation induced by juglone in LS-174T cells

a: marker. b-f: LS-174T cells were treated with juglone 0, 12, 25, 50, 100 $\mu \mathrm{M}$ for $36 \mathrm{~h}$. DNA was isolated by agarose gel electrophoresis and analyzed by ethidium bromide staining was also determined. Figure $4 \mathrm{~B}$ showed that the expression of minor PARP $(85 \mathrm{kDa})$ protein after cleavage was up-regulated by juglone, indicating that caspase- 3 is activated. Caspase- 3 activity was increased in a dose-dependent manner (Figure $4 \mathrm{C}$ ). These results correspond to the activation of caspase- 3 as shown in Figure 4A.

Mitochondrial Bcl-2 family is a series of proteins that regulate apoptosis. We measured the expressions of $\mathrm{Bcl}$ -2 by Western blot analysis. After incubation with juglone, expression of Bcl-2 protein was decreased (Figure 5).

The generation of ROS may be relate to apoptosis induced by juglone, therefore, we investigated the induction of apoptosis by juglone to determine if it was associated with ROS generation. To accomplish this, LS$174 \mathrm{~T}$ cells were pre-treated for 1 hour with $0.4,2$ and 10 $\mathrm{mM}$ NAC, a commonly used reactive oxygen intermediate scavenger. The cells were then treated with $50 \mu \mathrm{M}$ juglone for 36 hours. As shown in Figure $6 \mathrm{~A}$, pre-treatment with $\operatorname{NAC}(0.4,2$ and $10 \mathrm{mM})$ significantly blocked the inhibition induced by juglone $(\mathrm{p}<0.001)$. Furthermore, pre-treatment with $5 \mathrm{mM}$ NAC inhibited procaspase- 3 and -9 activation that was observed in LS-174T cells in response to juglone treatment. Additionally, we also found that pretreatment with $5 \mathrm{mM}$ NAC reversed juglone-induced Bcl-2 down-regulation (Figure 6B)

\section{Discussion}

Walnut has been used in traditional medicines for various ailments and some extracts of walnut are also 


\begin{tabular}{|c|c|c|c|c|c|c|}
\hline & 0 & 12 & 25 & 50 & $100(\mathrm{mM})$ & \\
\hline Procaspase-3 & 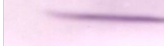 & 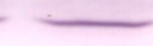 & $\longrightarrow$ & 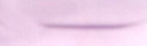 & & $35 \mathrm{Kda}$ \\
\hline Procaspase-9 & $=$ & 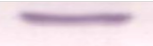 & $\longrightarrow$ & - & $\longrightarrow$ & $47 \mathrm{Kda}$ \\
\hline GAPDH & - & 7 & D. & $=$ & $\longrightarrow$ & $36 \mathrm{Kda}$ \\
\hline
\end{tabular}

Figure 4A: The expression of procaspase- 3 and procaspase-9 in 0, 12, 25, 50, $100 \mu \mathrm{M}$ juglone-treated LS-174T cells. The cells were treated with juglone 36 hours. Procaspase- 3 and procaspase- 9 were analysed by western blot. GAPDH was used as an equal loading control

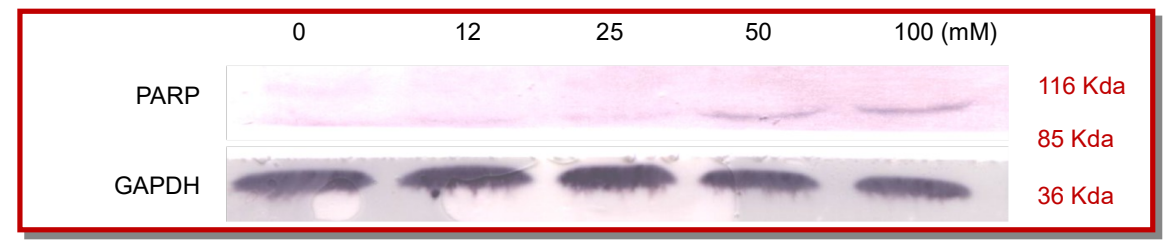

Figure 4B: The expression of PARP in 0, 12, 25, 50, $100 \mu \mathrm{M}$ juglone-treated LS-174T cells. The cells were treated with juglone 36 hours. PARP were analysed by Western blot. GAPDH was used as an equal loading control

reported to possess anticancer properties (Duke et al., 1998). However little has been reported about the mechanisms underlying the cytotoxic potential of juglone in LS-174T cells. In the present study, we found juglone, a main active ingredient in walnut, strongly inhibited the growth of LS-174T cells in a concentrationand time-dependent manner. Earlier, Segura-Aguilar and co-workers (1992) compared the effect of juglone and other quinones on human leukemic (HL-60) cells and doxorubicin-resistant human leukemic (HL-60R) cells and concluded that multidrug resistance that develops in the doxorubicin-resistant HL-60R cells had no effect on the cytotoxicity of juglone indicating its therapeutic possibilities (Segura-Aguilar et al., 1992). In addition, we did observe juglone-induced typical chromatin condensation and DNA fragmentation shown by Hoechst 33258 staining and ethidium bromide staining.

Caspases play an important role in apoptosis (Kwon et al., 2003). Caspase-3 is activated either by extrinsic pathway (death receptor mediated) or by intrinsic pathway (mitochondria dependent pathway) (Verhagen et al., 2000). Caspases are proteases that are activated during apoptosis, and cleave substrates such as PARP (Lazebnik et al., 1994). PARP (116 kDa), a DNA repair enzyme, is probably best characterized caspase substrate, which is cleaved during apoptosis to a $24 \mathrm{kDa}$ and a $85 \mathrm{kDa}$ fragment representing the $\mathrm{N}$ terminal DNA-binding domain and the C-terminal catalytic subunit, respectively. During apoptosis, PARP is selectively cleaved by several caspases, especially by caspase-3 (Lazebnik et al., 1994; Kaufmann et al., 1993). Detection of a $85 \mathrm{kDa}$ or $24 \mathrm{kDa}$ caspase cleavage

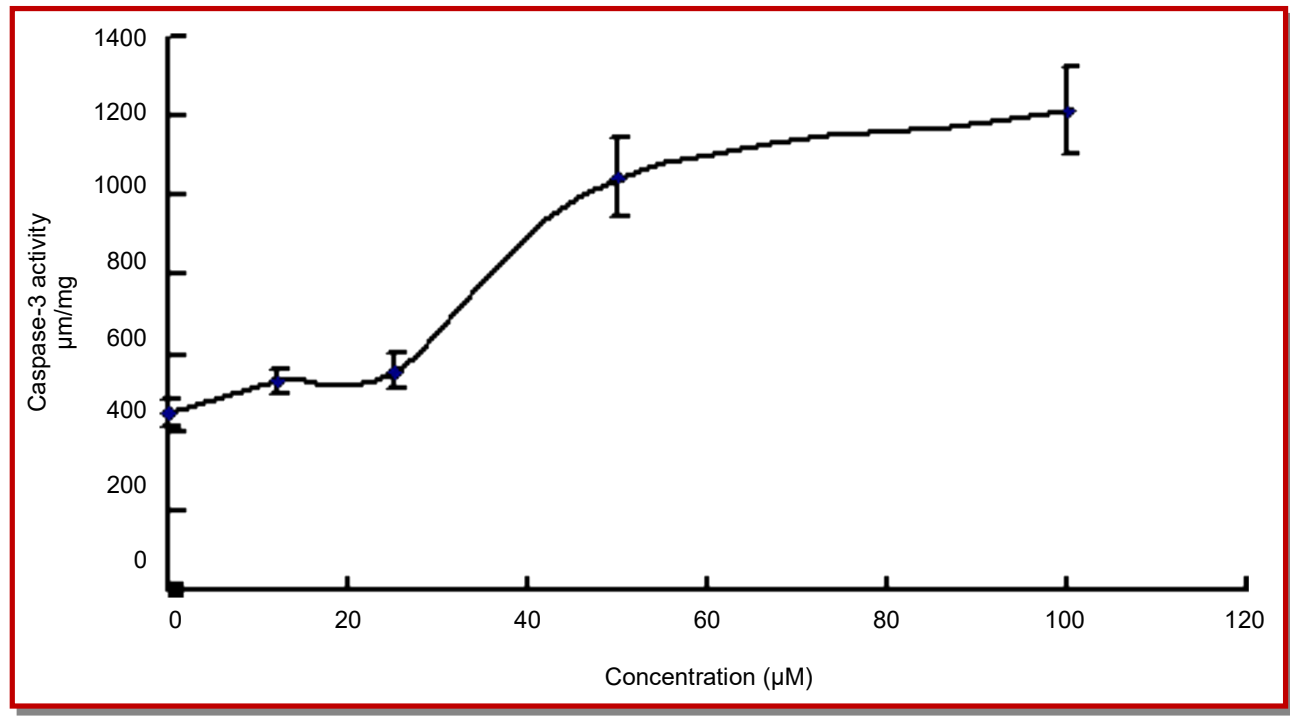

Figure 4C: Caspase-3 activity of juglone-treated LS-174T cells

The cells were treated with $0,12,25,50,100 \mu \mathrm{M}$ juglone for 36 hours ( ${ }^{* *}$ stands for $\mathrm{p}<0.01$ compared with $0 \mu \mathrm{M}$ ) 


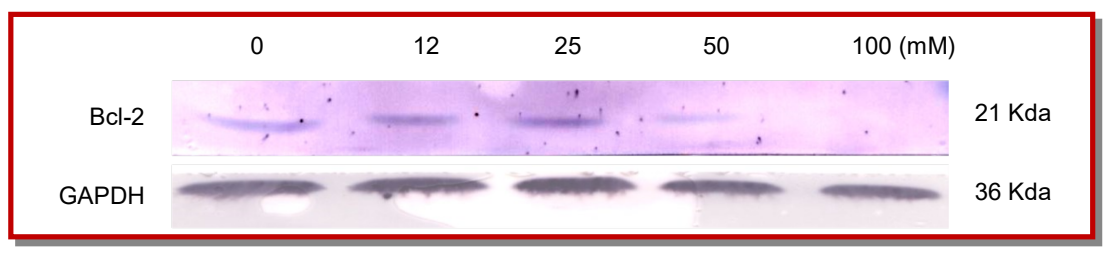

Figure 5: The expression of Bcl-2 in 0, 12, 25, 50, $100 \mu \mathrm{M}$ Juglone-treated LS-174T. The cells were treated with juglone 36 hours. Bcl-2 were analysed by western blot. GAPDH was used as an equal loading control

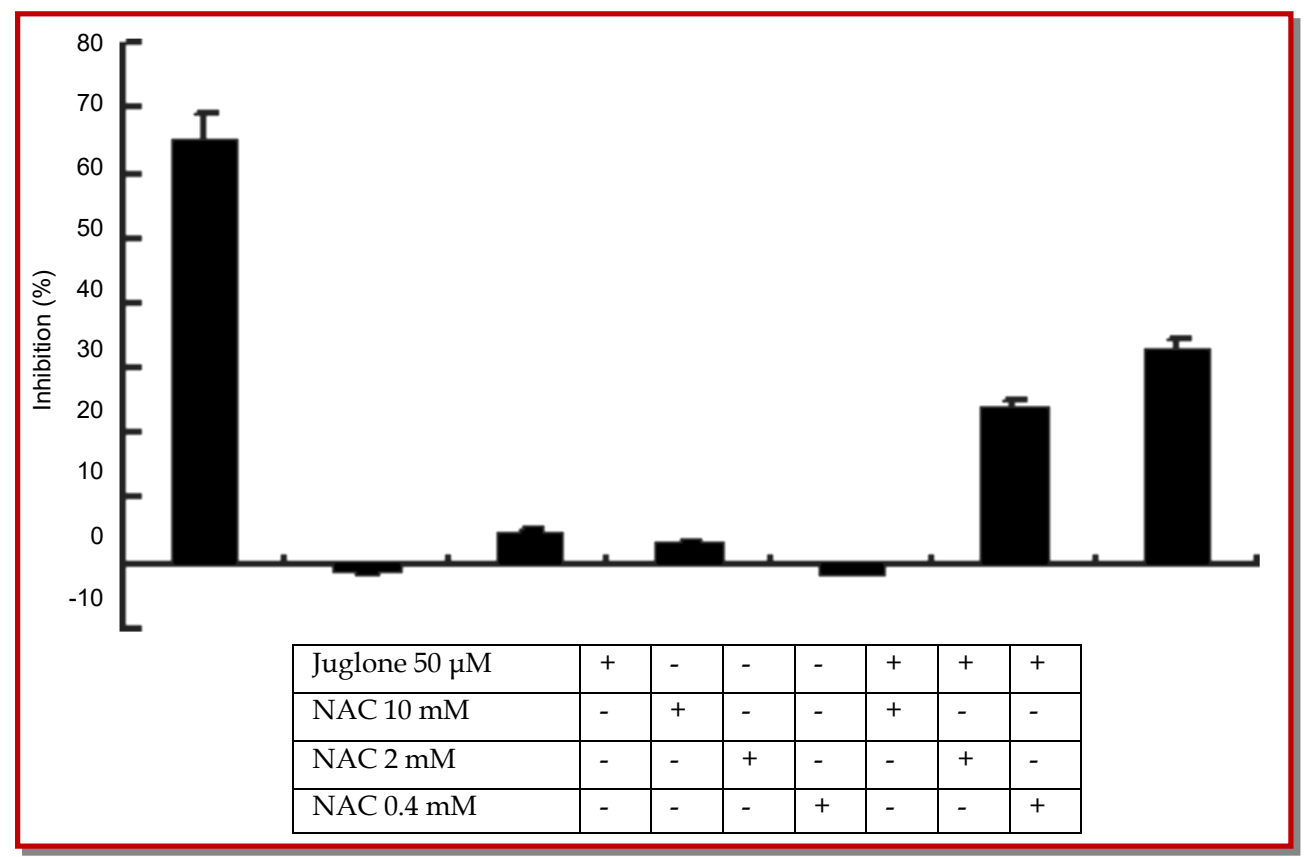

Figure 6A: Effect of NAC on juglone -induced cell death

One hour prior to the addition of $50 \mu \mathrm{M}$ juglone, LS-174T cells were treated with NAC (0.4, 2 and $10 \mathrm{mM})$, then incubated for 36 hours. The inhibition was measured by MTT method. ' $x \pm s, n=3\left({ }^{* * *}\right.$ stands for $\left.\mathrm{p}<0.001\right)$

fragment of PARP was shown to be a hallmark of apoptosis. In this paper, PARP minor $85 \mathrm{kDa}$ fragment expression was increased in a time dependent manner, and caspase-3 activity was also up-regulated in a concentration-dependent manner after treatment with juglone, which further confirmed that caspase- 3 is activated in jugone induced cell apoptosis.

It is widely accepted that alteration in mitochondrial structure and function play an important role in caspase -9 dependent apoptosis through releasing cytochrome $c$, which interacts with Apaf- 1 and procaspase- 9 to form the apoptosome. Then caspase- 9 was activated, which in turn cleaves and activated caspase-3, the executioner caspase, which cleaves PARP and activates endonucleases leading to DNA fragmentation. To verify whether mitochondrial pathway participates in jugloneinduced cell apoptosis, procaspase-9 protein was determined. The activation of caspase- 9 in jugloneinduced cell apoptosis strongly suggests an involvement of a mitochondrial pathway.

The Bcl-2 family of proteins serves as critical regulators of pathways involved in apoptosis (Adams et al., 1998).
The main protagonists are suggested to be antiapoptotic Bcl-2 and pro-apototic Bax. If the concentration of Bcl-2 is enough to complex with at least half of Bax, then apoptosis is prevented (Burlacu et al., 2003). In this paper, the Bcl-2 protein in juglonetreated LS-174T cells was down-regulated. This result suggested that the mitochondrial pathway of cell death might be involved in juglone -induced LS-174T cells death.

Induction of apoptosis by compounds such as arsenic trioxide $\left(\mathrm{As}_{2} \mathrm{O}_{3}\right)$ (Jing et al., 1999; Chen et al., 1998), tumor necrosis factor-a (TNF-a)( Larrick et al., 1990), ceramide (Quillet-Mary et al., 1997) and erbstatin (Shimizu et al., 1996) involves the production of ROS. In order to determine whether ROS participates jugloneinduced cells apoptosis, a water-soluble antioxidant, Nacetylcysteine (NAC) was used. NAC, a sulfhydryl group donor, serves as a precursor of GSH synthesis (Lauteburg et al., 1983) and inhibits the formation of extracellular reactive oxygen intermediates (Nakano et al., 1995). In this paper, juglone-induced cytotoxicity was markedly decreased by ROS scavenger NAC. In addition, activation of caspase- 3 and caspase- 9 was 


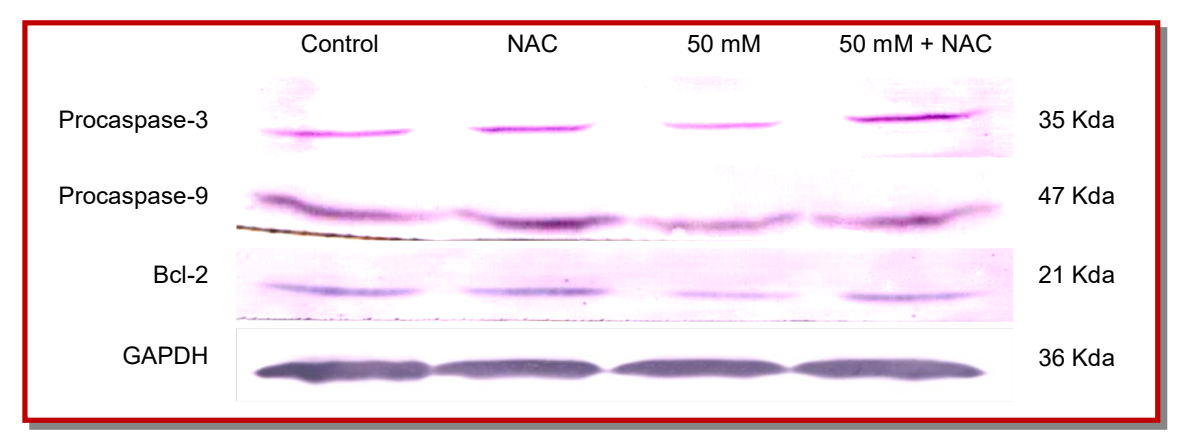

Figure 6B: Effect of NAC on juglone-induced procaspase-3 and procaspase-9 activation and Bcl-2 degradation. The cells were treated with $50 \mu \mathrm{M}$ juglone for $36 \mathrm{~h}$ in the presence or absence of $5 \mathrm{mM} \mathrm{NAC}$, followed by western blot analysis for detection of procaspase-3, procaspase- 9 and Bcl-2 expressions. GAPDH was used as an equal loading control

reversed by NAC and down-regulation of bcl-2 protein was also reversed, suggesting plausible role of ROS in juglone-induced apoptosis.

\section{Conclusion}

Our in vitro studies suggested that juglone could inhibit growth of LS-174T cells in a dose- and time-dependent manner. In addition, juglone was shown to induce apoptosis. This apoptotic response was associated with the down-regulation of Bcl-2 and activation of caspase-3 and -9 . Taken together, juglone may be a promising chemopreventive and chemotherapeutic agent against colon adenocarcinoma.

\section{References}

Adams JM, Cory S. The Bcl-2 protein family: Arbiters of cell survival. Science 1998; 281: 1322-26.

Babula P, Adam V, Havel L, Kizek R. Naphthoquinones and their pharmacological properties. Ceska Slov Farm. 2007; 56: 114-20.

Burlacu A. Regulation of apoptosis by Bcl-2 family proteins. J Cell Mol Med. 2003; 7: 249-57.

Chen YC, Lin-Shiau SY, Lin JK. Involvement of reactive oxygen species and caspase- 3 activation in arsenite-induced apoptosis. J Cell Phys. 1998; 177: 324-33.

Clark AM, Jurgens TM, Hufford CD. Antimicrobial activity of juglone. Phytother Res. 2006; 4: 11-14.

Inbaraj JJ, Chignell CF. Cytotoxic action of juglone and plumbagin: A mechanistic study using HaCaT keratinocytes. Chem Res Toxicol. 2004; 17: 55-62.

Ji YB, Qu ZY, Zou X. Juglone-induced apoptosis in human gastric cancer SGC-7901 cells via the mitochondrial pathway. Exp Toxicol Pathol. 2009; 63: 69-78.

Jing Y, Dai J, Chalmers-Redman RM, Tatton WG, Waxman S. Arsenic trioxide selectively induces acute promyelocytic leukemia cell apoptosis via a hydrogen peroxide-dependent pathway. Blood 1999; 94: 2102-11.

Kamei H, Koide T, Kojima T, Hashimoto Y, Hasegawa M.
Inhibition of cell growth in culture by quinones. Cancer Biother Radiopharm. 1998; 13: 185-88.

Kaufmann SH, Desnoyers S, Ottaviano Y, Davidson NE, Poirier GG. Specific proteolytic cleavage of poly (ADPribose) polymerase: An early marker of chemotherapyinduced apoptosis. Cancer Res. 1993; 53: 3976-85.

Kiran B. Juglone, a naphthoquinone from walnut, exerts cytotoxic and genotoxic effects against cultured melanoma tumor cells. Cell Biol Int. 2009; 33: 1039-49.

Kwon KB, Kim EK, Shin BC, Seo EA, Yang JY, Ryu DG. Herba houttuyniae extract induces apoptotic death of human promyelocytic leukemia cells via caspase activation accompanied by dissipation of mitochondria membrane potential and cytochrome c release. Exp Mol Med. 2003; 35: 91-97.

Larrick JW, Wright SC. Cytotoxic mechanism of tumor necrosis factor-a. FASEB J. 1990; 4: 3215-23.

Lauteburg BH, Corcoran GB, Mitchell JR. Mechanism of action of $\mathrm{N}$-acetylcysteine in the protection against the hepatotoxicity of acetaminophen in rats in vivo. J Clin Invest. 1983; 71: 980-91.

Lazebnik YA, Kaufmann SH, Desnoyers S, Poirier GG, Earnshaw WC. Cleavage of poly (ADP-ribose) polymerase by a proteinase with properties like ICE. Nature 1994; 371: $346-47$.

Li ZB, Wang JY, Jiang B, Zhang XL, An JL, Bao YM. Benzobijuglone, a novel cytotoxic compound from Juglans mandshurica, induced apoptosis in HeLa cervical cancer cells. Phytomedicine 2007; 14: 846-52.

Liu L, Li W, Koike K, Zhang S, Nikaido T. New alphatetralonylglucosides from the fruit of Juglans mandshurica. Chem Pharm Bull. 2004; 52: 566-69.

Nakano H, Boudjema K, Alexandre E, Imbs P, Chenard MP, Wolf P, Cinqualbre J, Jaeck D. Protective effects of Nacetylcysteine on hypothermic ischemia reperfusion injury of rat liver. Hepatology 1995; 22: 539-45.

Quillet-Mary A, Jaffrezou JP, Mansat V, Bordier C, Naval J, Laurent G. Implication of mitochondrial hydrogen peroxide generation in ceramide-induced apoptosis. J Biol Chem. 1997; 272: 21388-395.

Rippmann JF, Hobbie S, Daiber C, Guilliard B, Bauer M, Birk J, Nar H, Garin-Chesa P, Rettig WJ, Schnapp A. 
Phosphorylation-dependent proline isomerization catalyzed by Pin 1 is essential for tumor cell survival and entry into mitosis. Cell Growth Differ. 2000; 11: 409-16.

Rasu A, Song RM, Wei W, Nishino Y, Tsuji I, Li XM, Li J. Tubeimoside- 1 inhibits growth via the induction of cell cycle arrest and apoptosis in human melanoma A375 cells. Bangladesh J Pharmacol. 2012; 7: 150-56

Segura-Aguilar J, Jonsson K, Tidefelt U, Paul C. The cytotoxic effects of 5-OH-1, 4-naphthoquinone and 5,8-diOH-1,4naphthoquinone on doxorubicin-resistant human leukemia cells (HL-60). Leuk Res. 1992; 16: 631-37.
Shimizu S, Imoto M, Masuda N, Takada M, Umezawa K. Involvement of hydrogen peroxide production in erbstatininduced apoptosis in human small cell lung carcinoma cells. Cancer Res. 1996; 56: 4978-82.

Varga Z, Bene L, Pieri C, Damjanovich S, Gaspar Jr R. The effect of juglone on the membrane potential and whole-cell $\mathrm{K}+$ currents of human lymphocytes. Biochem Biophys Res Commun. 1996; 218: 828-32.

Verhagen AM, Ekert PG, Pakusch M, Silke J, Connoly LM, Reid GE, Moritz RL, Simpson RJ, Vaux DL. Identification of DIABLO, a mammalian protein that promotes apoptosis by binding and antagonizing IAP proteins. Cell 2000; 102: 43-53.

Author Info

Xian Feng Gong (Principal contact)

, e-mail: gongxianfeng@yahoo.com.cn

I - - - - - - - - - - - - - - - - - - - - - - - - - - - - - - - - - - - - - - - - - - - - - - - - - - - - - - 